NOTES ON LIVIA MACULIPENNIS (FITCH) (HOMOPTERA; CHERMID E)

\author{
By Harry B. Weiss and Erdman West
}

Highland Park, N. J.

This jumping plant louse which is recorded by Van Duzee ${ }^{1}$, as occurring in Quebec, New Hampshire, New York, Massachusetts New Jersey, Pennsylvania, District of Columbia and Alabama has been known for some time to be associated with the elongate gall on rush (Juncus sp.), the floral parts being aborted, the bracts of the inflorescence increasing to many times their normal size and forming closely imbricated clusters from 3 to $4 \mathrm{~cm}$., in length. For several years this species has been noted at Monmouth Junction, N. J., and the following notes have been accumulated.

The adult overwinters and appears during the middle and last of May. The oval, lemon-yellow eggs are deposited in rows on the inflorescence and bracts, each egg being fastened on the plant tissue by means of a short, backward projecting, basal stipe. A few eggs were found as late as June 17 after the galls were fully developed and these occurred on the inner surface of the lowest bract. After hatching the nymphs make their way to between the folded leaf-like parts, most of them feeding head downward between the sheaths. By the last week of June many are fully developed and the first adults emerge several days later. Most of the nymphs inhabit the outer sheaths and only a few are found in the tightly rolled inner sheaths. Some galls were found to contain from 25 to 100 nymphs. Those with fifty or more were quite swollen. The larger nymphs have the ends of their abdomens clothed loosely in waxy threads. As a rule nearly all nymphal stages can be found in a gall during the last of June, with the possible exceptions of newly hatched ones. Based on size and structure, the nymphs were easily arranged into five stages and the following descriptions indicate the development which takes place from egg to adult.

IVan Duzee, Cat. Hemip. Amer. North of Mexico. 
EGG. Length, $0.3 \mathrm{~mm}$. Greatest width $0.9 \mathrm{~mm}$. Lemon yellowish; elliptical, somewhat flattened on one side, bluntly pointed at distal end, basal end terminating in a short projecting stipe. First Nymphal Stage Length $0.4-0.45 \mathrm{~mm}$. Width of head across eyes, $0.12 \mathrm{~mm}$. Color, pale yellowish or whitish tinged with brown. General shape, subrectangular, somewhat flattened. Head truncate, slightly narrower than thorax; eyes red, lateral; antennæ erect, cone-shaped, tip truncate and bearing two hairs. Thorax with sides subparallel, slightly converging posteriorly, length about one-third greater than length of abdomen, segmentation indistinct. Abdomen subcircular to oval except where it joins the thorax, segmentation indistinct, fringed with a row of equidistant hairs. Sheath of rostrum extending almost to between second pair of legs. Legs short, chunky, gradually tapering toward tip which bears a sucker disk and two hairs.

Second Nymphal Stage. Length about $0.73 \mathrm{~mm}$. Width of head across eyes $0.22 \mathrm{~mm}$. similar to preceding stage in color, shape and general proportions.

Third Nymphal Stage. Length about $1.1 \mathrm{~mm}$. Width of head across eyes, $0.3 \mathrm{~mm}$. Color, shape and general proportions somewhat similar to those of preceding stage. Dorsal surface of thorax bears brownish spots. Upper surface of last few abdominal segments brownish. Tips of legs and tips of antennæ brownish. Sides of mesothorax produced laterally into pronounced pads. Sides of metathorax produced laterally into pads less pronounced than those of mesothorax. Abdomen about as long as thorax, more oval in shape than formerly and with a more decided yellowish tinge, tip clothed with many fine hairs. Fourth Nymphal Stage. Length about $1.7 \mathrm{~mm}$. Width of head across eyes $0.5 \mathrm{~mm}$. Yellowish white. Head as wide as thorax broadly rounded anteriorly. Eyes, red, prom nent, lateral. Antennæ conical, erect, as long as width of head between antennæ. Thorax subrectangular, about as long as abdomen, sides parallel, dorsal surface bearing several brownish spots. Wing pads large, pronounced extending obliquely, posteriorly. Wing pads bearing few short hairs. Abdomen oval, constricted somewhat anteriorly, strongly convex, segmentation indistinct, apical 
segments covered dorsally by a somewhat chitinous plate, tip and sides sparsely clothed with short hairs. Legs chunky. Sheath of rostrum extending to between first and second pairs of legs.

Fifth Nymphal Stage. Length about $2.5 \mathrm{~mm}$. Width of head across eyes, $0.6 \mathrm{~mm}$. Color pale or dirty yellowish tinged with brown. Tips of antennæ, tips of legs and edges of wing pads somewhat brownish. Ventral surface pale. Head and thorax subequal in width. Eyes, lateral, prominent, red. Head and almost all of dorsal surface of first thoracic segment except for a broad, median line on head and thorax covered by a light brownish chitinous area. Prothorax two-thirds as long as mesothorax. Metathorax slightly less than one-half as long as prothorax. Wing pads of mesothorax extending to beginning of first abdominal segment. Wing pads of metathorax extending almost to end of second abdominal segment. Dorsal surface of mesothorax bearing a small, brown area and a dot on the anterior margin each side of a median line; on posterior margin a large brown area and three closely placed darker spots or dots on each side of median line. Metathorax bears dorsal areas and spots similar to those of mesothorax. Anterior edge of first abdominal segment bears areas and spots similar to those on anterior edge of metathorax. Abdomen subcircular, strongly convex. First segment narrowed, gradually widening to fourth and then narrowing to broadly rounded extremity. First six abdominal segments distinct, remainder fused and covered with a darker, dorsal, chitinous plate; a tubercular, process on each side of anal opening. Sides and tip of abdomen bearing short hairs Dorsal surface of abdomen has a velvety appearance. Antennæ, head, wing pads and legs bearing several short hairs. Adult. This was described by Fitch in 1857 (Ann. Rept. N. Y. State Agric. Soc. XVII, p. 740) from specimens collected during the middle of May in extensive tracts of sweet flag (Acorus Calamus) growing on the banks of the Raritan River two miles below New Brunswick, N. J. His description follows.

“Spotted winged Diraphia, Diraphia maculipennis N. sp. 
This is a smaller species, measuring but 0.10 to the tips of its wings, and is tawny red, with the thorax tinged more or less with dusky, the antennæ with a broad black band towards their tips, the anterior wings more short and broad than in any of the other species, and hyaline with a broad smoky brown band on their tips, a spot back of the shoulder and some freckles near the margin also smoky brown, the veins, including the marginal, all white alternated with numerous black rings, the breast and hind breast blackish and the legs dusky brown tinged more or less with tawny vellow."

Miss Edith M. Patch has referred to this species several times and these references can be found in Van Duzee's catalogue. In Pysche (vol. XIX, p. 6,1912) Miss Patch places Provancher's Livia bifasciata as a synonym of maculipennis.

This insect which has commonly been known as the sedge psyllid has for its most conspicuous host a Juncus which is a plant belonging not to the "sedges" but to the "rushes", hence it might be called more correctly, the rush psyllid.

\section{HEMIPTEROLOGICAL NOTES'.}

By Roland F. Hussey, Forest Hills, Mass.

During the summers of $1920,1921,1922$, I found a very agile species of Orthotylus abundant on the hollyhocks in the grounds of the University Observatory at Ann Arbor, Michigan. From June until late September, at least, adults and nymphs were numerous, occurring on the upper side of the leaves, and the plants showed plainly the effect of their work. At the time when I first collected this form, I was unable to identify it with any described species of the genus, but subsequently I 

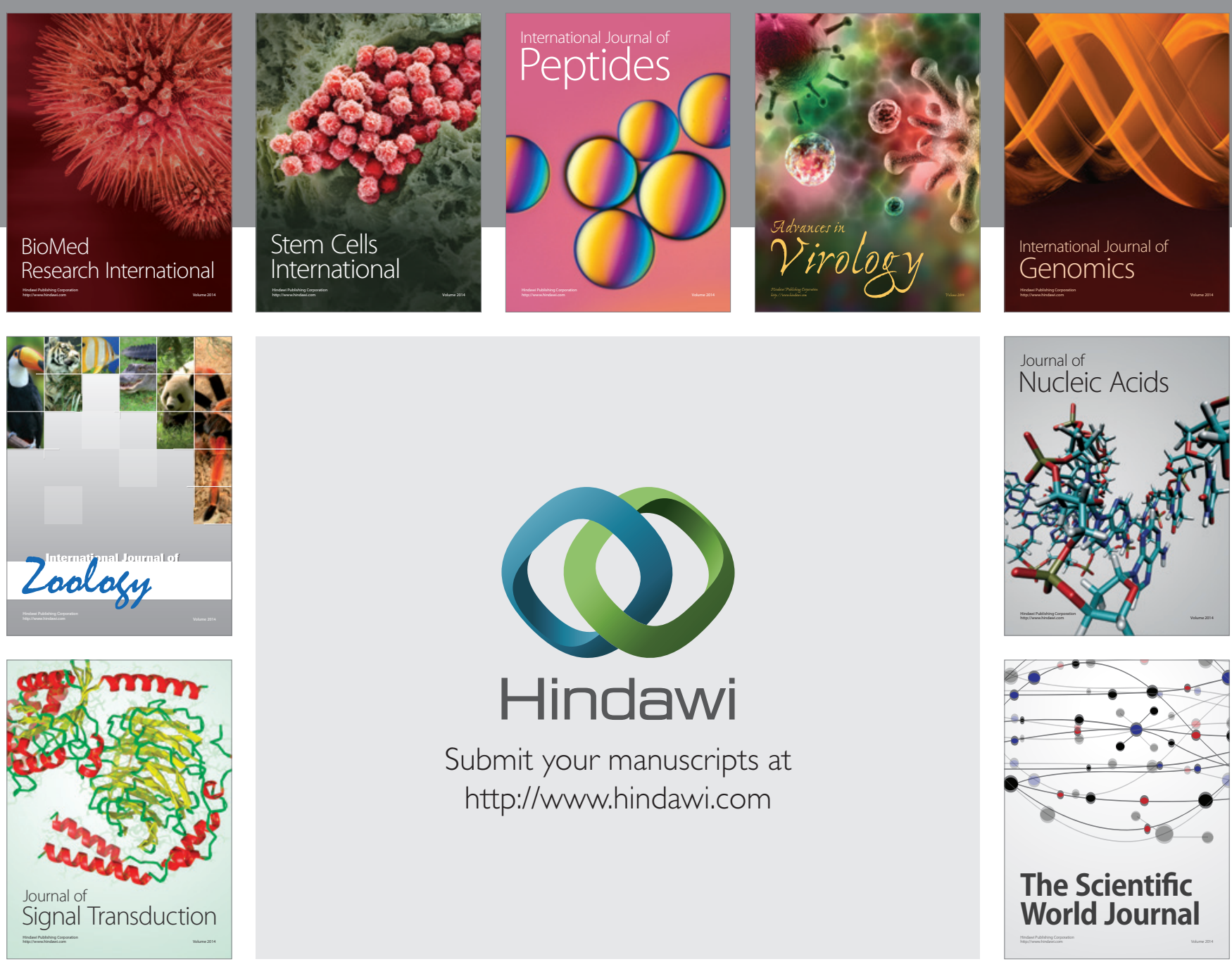

Submit your manuscripts at

http://www.hindawi.com
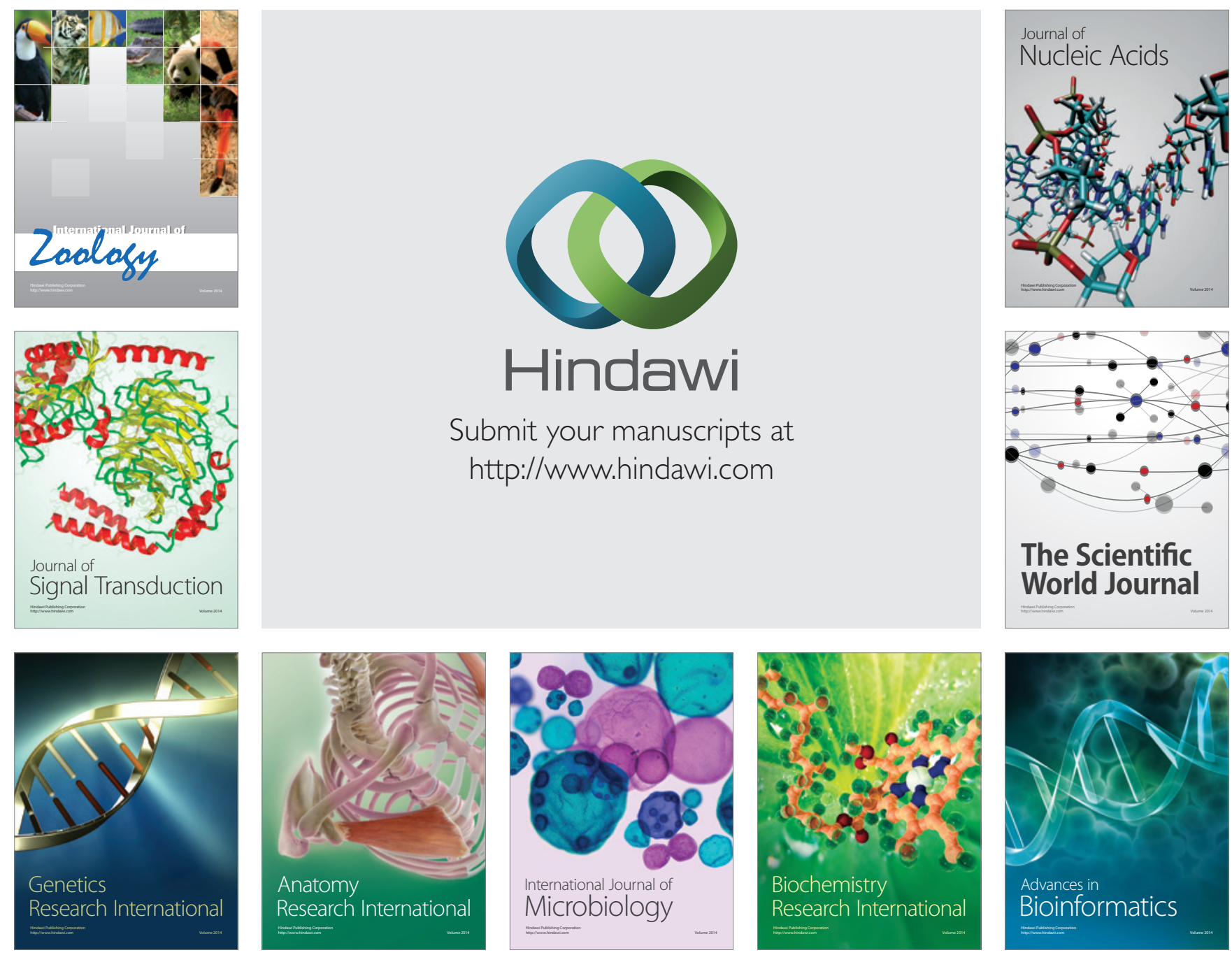

The Scientific World Journal
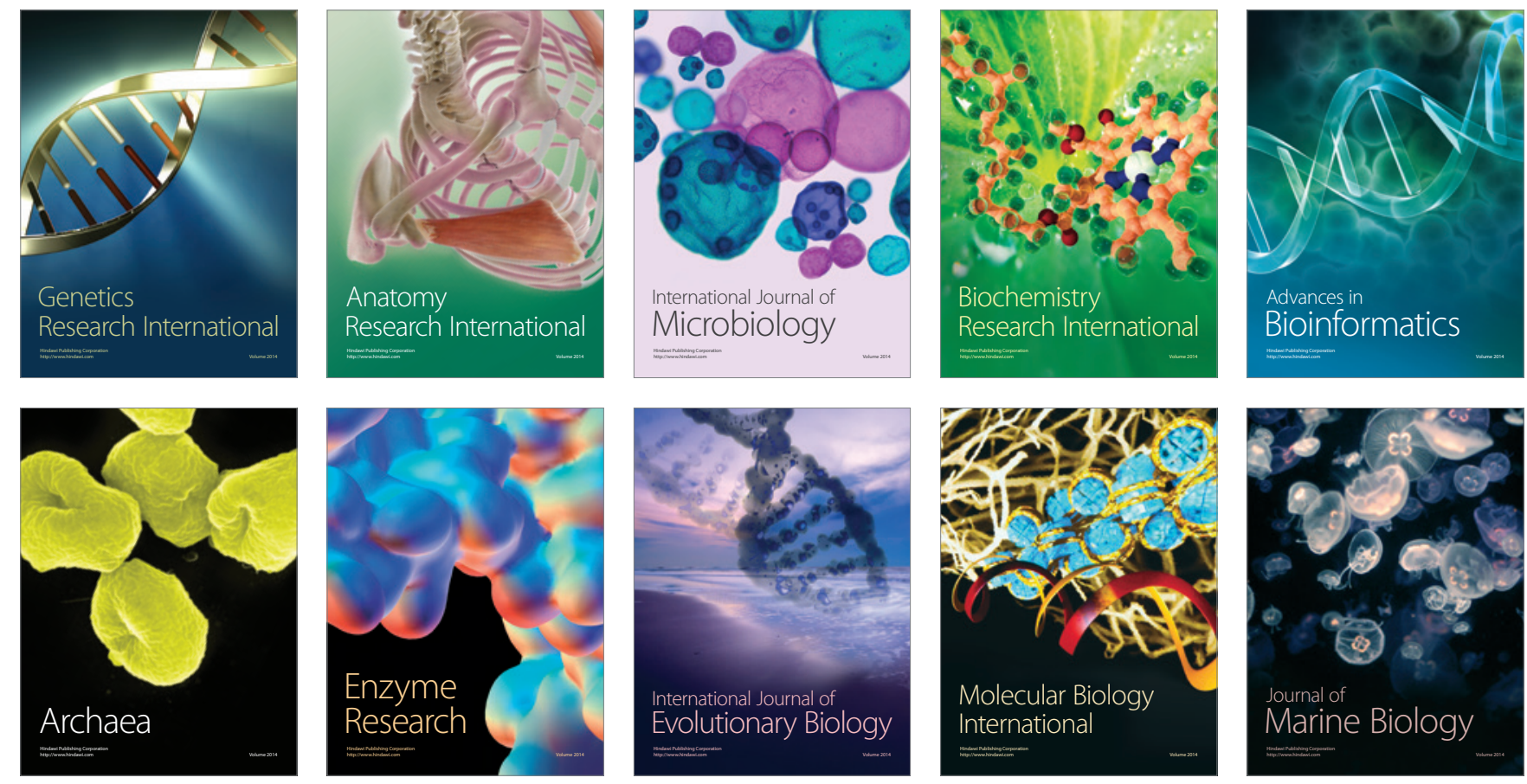